\title{
Ethno-botanical survey for wild plants in fringe villages around Shimla Water Catchment Sanctuary, Himachal Pradesh, India
}

\author{
Dipika Rana ${ }^{1 *}$ and Haseeb Ul Rashid Masoodi ${ }^{2}$ \\ ${ }^{1}$ Himalayan Forest Research Institute, Panthaghati, Shimla-171009 (H.P.), INDIA \\ ${ }^{2}$ Forest Research Institute, Dehradun, Uttarakhand, INDIA \\ *Corresponding author. E-mail:dipikahfri@gmail.com
}

Received: June 25, 2014; Revised received: September 23, 2014; Accepted: November 30, 2014

\begin{abstract}
In this study an ethno-botanical survey was carried out in the fringe villages located at the periphery of Shimla Water Catchment Sanctuary. As the sanctuary area is not completely fenced the villagers have an access inside the sanctuary. An attempt was made to prepare a document of important flora and information from local community about their ethnic uses. The indigenous knowledge of local traditional uses was collected by personal interviews during field trips. Plants with their correct nomenclature were arranged by family name, vernacular name, part use, ethno-botanical remedies and uses. Plants having uses in medicine, ornamental, fodder and many other were studied. The study was entirely focused on revealing the medicinal potential possessed by the plants growing wild in this area and their sustainability for the betterment of mankind.
\end{abstract}

Keywords: Catchment, Ethno-botanical, Fringe village, Sanctuary

\section{INTRODUCTION}

Himachal Pradesh is a hilly state situated in the Western Himalaya in India with an altitude ranging from $350 \mathrm{~m}$ to $7000 \mathrm{~m}$ above mean sea level and covers an area of 55,673 sq. km. This hilly state comprises a good

heritage of ethno-botanical flora and natural wealth in the North Western Himalayan region between $30^{0} 22^{\prime} 44^{\prime \prime} \mathrm{N}$ to $33^{\circ} 12^{\prime} 44^{\prime \prime} \mathrm{N}$ latitude and $75^{\circ} 45^{\prime} 44^{\prime \prime} \mathrm{E}$ to $79^{0} 04^{\prime} 20^{\prime}$ 'E longitude. A popular tourist destination, Shimla is often referred to as the "Queen of Hills" a term coined by the British. In 1864, Shimla was declared the summer capital of the British rule in India. Nature has bestowed this state with a very rich botanical wealth and a large number of diverse plants. From time immemorial, the indigenous communities, all over the world, have been depending upon the ambient natural resources for their sustenance.

Regarding the earlier publications, the state of Himachal Pradesh has been extensively explored floristically by various workers (Atkinson (1882), Hooker (1872-1897), Collett (1902)), with emphasis on taxonomy. Studies on diversity of medicinal and aromatic plants in different regions of the state have also been known, viz. Kangra valley Ahluwalia, (1952); Uniyal and Chauhan, (1971), Kullu Rastogi, (1960);

Dobriyal et al. (1997), Chamba (Gupta, 1961, 1971); Shabnam (1964). Verma et al. (2012) conducted studies on ethno-medico-botany of Kunihar forest division of Solan district and reported 195 species as ISSN : 0974-9411 (Print), 2231-5209 (Online) All Rights Reserved ๑ Applied and Natural Science Foundation www.ansfoundation.org medicinal and aromatic plants used by the local inhabitants for curing various diseases. Account of 25 ethno-medicinal plants of Kanag hill, Shimla has been given by Verma et al. (2012). Comparatively, information pertaining to folk and ethno-botanical practices is scanty for Shimla in general and Shimla Water Catchment Sanctuary in particular.

Hence, an attempt has been made to document the precious indigenous wisdom on the multifaceted usage of plants from Shimla Water Catchment Sanctuary with a view not only to conserve it from being lost irreversibly from growing anthropogenic pressures but also for using them as valuable clues for social forestry endeavors and sustainable management of species as well as their habitats.

\section{MATERIALS AND METHODS}

Shimla Water Catchment Sanctuary derives its name from hydrological functions it is performing from past 120 years. The sanctuary lies in between the altitudes of $1850 \mathrm{~m}-2750$ above msl and is drained by a number of seasonal streams which eventually converge into perennial streams. The sanctuary has an area of 1020.32 ha and lies between $31^{\circ} 05^{\prime}$ to $31^{\circ} 75^{\prime} \mathrm{N}$ latitude and $77^{0} 12$ ' to $77^{0} 15^{\prime} \mathrm{E}$ longitudes. The climate of Shimla is predominantly cool during winters and moderately warm during summer. Temperatures typically range from $-6^{\circ} \mathrm{C}$ to $31^{\circ} \mathrm{C}$ over the course of a year. Monthly precipitation varies between $15 \mathrm{~mm}$ in November to $434 \mathrm{~mm}$ in August. There are no villages inside the sanctuary, but on the periphery there are 10 
Table 1. Ethno-medicinal uses of some wild plants of area in and around Shimla Water Catchment Sanctuary.

\begin{tabular}{|c|c|c|c|c|c|}
\hline $\begin{array}{l}\text { S. } \\
\text { No. }\end{array}$ & Botanical name & Family & $\begin{array}{l}\text { Local } \\
\text { name }\end{array}$ & Part used & Folk uses \\
\hline 1. & $\begin{array}{l}\text { Achyranthes aspera } \\
\text { Linn }\end{array}$ & Amaranthaceae & Puth-kanda & $\begin{array}{l}\text { Leaves. } \\
\text { Roots. Seeds }\end{array}$ & $\begin{array}{l}\text { Powdered roots mixed with } \\
\text { honey given for cough and } \\
\text { hemorrhoids. Root paste } \\
\text { consumed to check bleeding } \\
\text { after abortion. Leaf paste } \\
\text { applied to heal bites of poisonous } \\
\text { insects, wasp, and bees. Seeds } \\
\text { considered highly nutritious. }\end{array}$ \\
\hline 2. & Adhatoda vasica Nees & Acanthaceae & $\begin{array}{l}\text { Basuti, } \\
\text { Vasaka }\end{array}$ & $\begin{array}{l}\text { Whole Plant, } \\
\text { Leaves, } \\
\text { Roots. }\end{array}$ & $\begin{array}{l}\text { Crushed plant impart specific } \\
\text { flavor to local wine. Leaves } \\
\text { and roots useful in asthma, } \\
\text { bronchitis, cough, rheumatism } \\
\text { and as insecticide. }\end{array}$ \\
\hline 3. & Ainsliaea aptera DC & Asteraceae & $\begin{array}{l}\text { Chiri-ka- } \\
\text { bhat }\end{array}$ & $\begin{array}{l}\text { Flowers. } \\
\text { Whole Plant. }\end{array}$ & $\begin{array}{l}\text { Flowers consumed for their } \\
\text { nectar. Plant employed for } \\
\text { fodder purposes. }\end{array}$ \\
\hline 4. & $\begin{array}{l}\text { Arisaema tortuosum } \\
\text { Schott }\end{array}$ & Araceae & Kira-aloo & Whole Plant. & $\begin{array}{l}\text { Plant used for its insecticidal } \\
\text { and pesticidal properties. }\end{array}$ \\
\hline 5. & $\begin{array}{l}\text { Asparagus racemosus } \\
\text { Willd. }\end{array}$ & Liliaceae & Satawar & $\begin{array}{l}\text { Tuberous } \\
\text { roots, } \\
\text { Leaves. }\end{array}$ & $\begin{array}{l}\text { Decoction of leaves applied to } \\
\text { check skin eruptions. Plant } \\
\text { given as fodder. Powdered } \\
\text { roots }(2-3 \mathrm{~g}) \text { consumed with } \\
\text { milk for enhancing vigour and } \\
\text { vitality. }\end{array}$ \\
\hline 6. & Berberis lycium Royle & Berberidaceae & Kashmal & $\begin{array}{l}\text { Tender } \\
\text { Shoot. Fruits. }\end{array}$ & $\begin{array}{l}\text { Ripe fruits edible. Tender } \\
\text { shoots chewed for curing skin } \\
\text { diseases and as blood purifier. }\end{array}$ \\
\hline 7. & $\begin{array}{l}\text { Bergenia ciliata } \\
\text { (Haw.) Sternb. }\end{array}$ & Saxifragaceae & $\begin{array}{l}\text { Pashan- } \\
\text { bhed }\end{array}$ & $\begin{array}{l}\text { Rhizome, } \\
\text { Leaves, } \\
\text { Flowers. }\end{array}$ & $\begin{array}{l}\text { Decoction of rhizome } \\
\text { prescribed to cure fever and } \\
\text { swollen joints. Leaves kept to } \\
\text { check fever. Flowers used for } \\
\text { pickling and culinary preparations. }\end{array}$ \\
\hline 8. & Bidens pilosa Linn. & Asteraceae & $\begin{array}{l}\text { Badi- } \\
\text { gumbri }\end{array}$ & $\begin{array}{l}\text { Flowers, } \\
\text { Whole Plant. }\end{array}$ & $\begin{array}{l}\text { Flowers used for ornamental } \\
\text { purposes. Plant used as fodder } \\
\text { for enhancing milk production } \\
\text { in domestic animals. }\end{array}$ \\
\hline 9. & $\begin{array}{l}\text { Boenninghausenia } \\
\text { albiflora Hook.s }\end{array}$ & Rutaceae. & Pissumar & $\begin{array}{l}\text { Aerial Plant } \\
\text { Parts }\end{array}$ & $\begin{array}{l}\text { Aerial plant parts good for } \\
\text { healing wounds. }\end{array}$ \\
\hline 10. & Cannabis sativa Linn. & Cannabinaceae & Bhaang & Leaves & $\begin{array}{l}\text { Crushed leaves mixed with } \\
\text { milk, sugar and dry fruits used } \\
\text { in the preparation of 'ghota' on } \\
\text { the day of Shivratri and } \\
\text { distributed as 'prasadam' to } \\
\text { devotees visiting the temple. }\end{array}$ \\
\hline 11. & $\begin{array}{l}\text { Capsella bursa- } \\
\text { pastoris (L.) Moench. }\end{array}$ & Brassicaceae & Seksi & Leaves & $\begin{array}{l}\text { Plant used for its insecticidal } \\
\text { properties. }\end{array}$ \\
\hline 12. & Celtis australis Linn. & Ulmaceae & Khidak & $\begin{array}{l}\text { Roots, } \\
\text { Young } \\
\text { Branches }\end{array}$ & $\begin{array}{l}\text { Paste of root applied on cuts } \\
\text { and wounds. Young branches } \\
\text { relished by cattle. }\end{array}$ \\
\hline 13. & $\begin{array}{l}\text { Delphinium } \\
\text { denudatum Wall. } \\
\text { ex Hook }\end{array}$ & Ranunculaceae. & Nirbisi. & Whole Plant. & $\begin{array}{l}\text { Plant juice applied on cuts for } \\
\text { immediate relief and healing. } \\
\text { Plant grown for its ornamental } \\
\text { value. }\end{array}$ \\
\hline
\end{tabular}


Table 1. Contd.

\begin{tabular}{|c|c|c|c|c|c|}
\hline 14. & Diplazium esculentum & Athyriaceae & Lingdi & Whole plant & Cooked as vegetable \\
\hline 15. & Fragaria indica Andr. & Rosaceae & Aakhe & Friut & Ripe fruits edible. \\
\hline 16. & $\begin{array}{l}\text { Geranium wal- } \\
\text { lichianum Sweet }\end{array}$ & Geraniaceae & Bhanda & Root & $\begin{array}{l}\text { Decoction of roots considered } \\
\text { good for expelling kidney } \\
\text { stones. }\end{array}$ \\
\hline 17. & Hedera helix Linn. & Araliaceae & Dakari & $\begin{array}{l}\text { Fruits, } \\
\text { Leaves, } \\
\text { Whole Plant }\end{array}$ & $\begin{array}{l}\text { Leaves and berries taken orally } \\
\text { as an expectorant to treat cough } \\
\text { and bronchitis and cultivated as } \\
\text { an ornamental plant. }\end{array}$ \\
\hline 18. & $\begin{array}{l}\text { Hypericum cernuum } \\
\text { Roxb. }\end{array}$ & Hypericaceae & Suchi & Seed & $\begin{array}{l}\text { Seeds used for flavoring curries. } \\
\text { Seed oil massaged for quick } \\
\text { relief of rheumatism. }\end{array}$ \\
\hline 19. & Impatiens sulcata & Balsaminaceae & $\begin{array}{l}\text { Neeru } \\
\text { ghas }\end{array}$ & Whole plant & $\begin{array}{l}\text { Grounded to make paste and } \\
\text { applied on eruptions of skin }\end{array}$ \\
\hline 20. & Inula cuspidata & Asteraceae & Poshkar. & Fresh Root. & $\begin{array}{l}\text { Decoction of fresh roots }(5-10 \mathrm{ml} \\
\text { for } 5 \text { days) empty stomach to } \\
\text { expel worms }\end{array}$ \\
\hline 21. & $\begin{array}{l}\text { Jasminum grandiflorum } \\
\text { Linn. }\end{array}$ & Oleaceae & Chameli & $\begin{array}{l}\text { Leaves, } \\
\text { Flowers. }\end{array}$ & $\begin{array}{l}\text { Leaves chewed for healing } \\
\text { mouth ulcer and gum infection. } \\
\text { Oil from flowers used in skin } \\
\text { disorders, headache and eye } \\
\text { ailments. }\end{array}$ \\
\hline 22. & Jasminum humile Linn. & Oleaceae & Jasmine & $\begin{array}{l}\text { Leaves, } \\
\text { Flowers }\end{array}$ & $\begin{array}{l}\text { Leaf paste applied for healing } \\
\text { wounds and boils. Poultice of } \\
\text { flowers good against headache. }\end{array}$ \\
\hline 23. & Juglans regia & Juglandaceae & Akhrot & Bark & $\begin{array}{l}\text { The root bark is used for the } \\
\text { cleaning of teeth and prevent it } \\
\text { from } \\
\text { decaying. }\end{array}$ \\
\hline 24. & Malva verticillata Linn. & Malvaceae. & Shotli & $\begin{array}{l}\text { Leaves, } \\
\text { Whole Plant. }\end{array}$ & $\begin{array}{l}\text { Aerial parts especially leaves, } \\
\text { consumed as vegetable. Plant } \\
\text { grown for ornamental purposes. }\end{array}$ \\
\hline 25. & Morchella esculenta & Fungi & Gucchii & Whole plant & Edible \\
\hline 26. & Plantago tibetica & Plantaginaceae & Isabgol & & Medicine to treat constipation \\
\hline 27. & Prinsepia utilis Royle & Rosaceae & Bhekal & Fruit, Seed & $\begin{array}{l}\text { Ripe fruits eaten. Seed oil used } \\
\text { for massaging rheumatic joints. }\end{array}$ \\
\hline 28. & $\begin{array}{l}\text { Quercus } \\
\text { leucotrichophora } \\
\text { Camus. }\end{array}$ & Fagaceae & Ban & Seed & $\begin{array}{l}\text { Decoction of seeds }(10 \mathrm{ml} \text {, thrice } \\
\text { daily) given for checking } \\
\text { dysentery and diarrhoea. }\end{array}$ \\
\hline 29. & $\begin{array}{l}\text { Ranunculus laetus } \\
\text { Linn. }\end{array}$ & Ranunculaceae & Changer & Leaves & Leaves consumed as vegetable. \\
\hline 30. & $\begin{array}{l}\text { Rhododendron } \\
\text { arboreum }\end{array}$ & Ericaceae & Brass & Flowers & Flowers used to make juice \\
\hline 31. & Rosa moschata Mill. & Rosaceae & $\begin{array}{l}\text { Jangli } \\
\text { gulab }\end{array}$ & Whole Plant & $\begin{array}{l}\text { Plant known for its ornamental } \\
\text { value. }\end{array}$ \\
\hline 32. & Rubus ellipticus $\mathrm{Sm}$. & Rosaceae & Aakhe & Fruit & Ripe fruits edible. \\
\hline 33. & Rubus niveus Wall. & Rosaceae & Aakhe & Fruits & Ripe fruits edible \\
\hline 34. & Rumex hastatus Don. & Polygonaceae & Khatmith & Aerial parts & $\begin{array}{l}\text { Aerial parts refreshing and eaten } \\
\text { raw. Also, given as fodder to } \\
\text { cattle. }\end{array}$ \\
\hline 35. & Rumex nepalensis Spr. & Polygonaceae & $\begin{array}{l}\text { Jugli } \\
\text { palak }\end{array}$ & Leaves & $\begin{array}{l}\text { Fresh leaves cooked as } \\
\text { vegetable. }\end{array}$ \\
\hline
\end{tabular}


Table 1. Contd.

\begin{tabular}{|c|c|c|c|c|c|}
\hline 36. & Smilax aspera Linn. & Liliaceae & Bragh bel & Shoot, Root & $\begin{array}{l}\text { Young shoots cooked as a } \\
\text { vegetable and also pickled. } \\
\text { Pieces of roots added in the } \\
\text { preparation of soups. }\end{array}$ \\
\hline 37. & Sonchus asper (L.) Hill & Asteraceae & Didhi & Latex & $\begin{array}{l}\text { Latex applied for quick } \\
\text { healing of wounds, cuts and } \\
\text { considered antiseptic. }\end{array}$ \\
\hline 38. & Stellaria media (L.) Vill. & Caryophyllaceae & Phulke & Whole plant. & $\begin{array}{l}\text { Plant consumed as a } \\
\text { vegetable. }\end{array}$ \\
\hline 39. & $\begin{array}{l}\text { Taraxacum officinale } \\
\text { Wigg. }\end{array}$ & Asteraceae & Kadavi & $\begin{array}{l}\text { Leaves, } \\
\text { Latex }\end{array}$ & $\begin{array}{l}\text { Leaves consumed as } \\
\text { vegetable; its decoction } \\
\text { prescribed against irritating } \\
\text { bowls. Latex applied for } \\
\text { quick healing of wounds. }\end{array}$ \\
\hline 40. & $\begin{array}{l}\text { Taxus baccata L. subsp. } \\
\text { wallichiana }\end{array}$ & Taxaceae & Rakhal & Leaves & $\begin{array}{l}\text { Leaves are collected for the } \\
\text { production of 'Taxol' which } \\
\text { is used for the cure of } \\
\text { cancer. The bark is also } \\
\text { used for preparation of tea. }\end{array}$ \\
\hline 41. & Thalictrum foliolosum & Ranunculaceae & Chirata & Whole plant & $\begin{array}{l}\text { Juice of leaves in skin } \\
\text { infections. }\end{array}$ \\
\hline 42. & Thymus vulgaris Roxb. & Lamiaceae & Ban- ajwain & $\begin{array}{l}\text { Leaves, } \\
\text { Flowers, } \\
\text { Whole Plant. }\end{array}$ & $\begin{array}{l}\text { Poultice of leaves and } \\
\text { flowers applied to check } \\
\text { headache. Plant grown for } \\
\text { ornamental purposes. }\end{array}$ \\
\hline 43. & Vicia hirsuta (L.) Koch & Fabaceae & Choti Kaer & $\begin{array}{l}\text { Aerial Plant } \\
\text { Parts, Seed }\end{array}$ & $\begin{array}{l}\text { Aerial parts cooked as } \\
\text { vegetable. Seeds also eaten. }\end{array}$ \\
\hline 44. & Viola serpens Wall & Violaceae & Banapsha & Flowers & $\begin{array}{l}\text { Flowers eaten as such for } \\
\text { irritating throat and also for } \\
\text { flavouring tea. }\end{array}$ \\
\hline 45. & Vitex negundo Linn. & Verbenaceae & Bana, Suro & Leaves & $\begin{array}{l}\text { Leaf paste applied to heal } \\
\text { swollen rheumatic joints. }\end{array}$ \\
\hline 46. & $\begin{array}{l}\text { Zanthoxylum alatum } \\
\text { Roxb. }\end{array}$ & Rutaceae & Tirmir & $\begin{array}{l}\text { Leaves, } \\
\text { Fruit, } \\
\text { Branches }\end{array}$ & $\begin{array}{l}\text { Fruits edible and used for } \\
\text { flavoring curries. Tender } \\
\text { leaves used for making } \\
\text { chutney. Branches used for } \\
\text { brushing teeth. Wood used } \\
\text { for making walking sticks. }\end{array}$ \\
\hline
\end{tabular}

villages in the vicinity of the sanctuary. In practical terms only Chharabra, Kufri and Dhalli situated towards its north, east and west respectively have a significant impact on the sanctuary. Reconnaissance survey was undertaken and personal interviewing during field trips was done with local people in the fringe villages of the sanctuary was undertaken to know the indigenous and traditional uses of the plants. The specimens with their correct nomenclature were arranged by family name, vernacular name, part use, ethno-botanical remedies and uses. Plants having uses in medicine, ornamental, fodder etc. were studied.

\section{RESULTS}

Traditional knowledge provides useful leads for scientific research, being the key to identify those plants which have high economic value and requires conservation in near future, thereby emphasizing the need for such studies. The reasons of the wide use of forest products may be many like lack of modern communications, poverty, ignorance and unavailability of modern health facilities etc. thereby, most people especially rural people are still forced to practice traditional medicines for their common day ailments. The list of villages located at the periphery of the sanctuary area which were relocated in the past was generated. Table1. The results in context to the ethno-botanical survey showed that 46 plants of ethno-botanical uses were present in and around the sanctuary area. The majority of plants belonged to family Asteraceae (5 spp.), Rosaceae (5 spp.), Ranunculaceae (3 spp.), Liliaceae, Oleaceae, Rutaceae, Polygonaceae (3 spp.) and others (1 spp. each).

\section{DISCUSSION}

India has a rich heritage of use of plants as medicines 
and Indian system of medicines utilizes $80 \%$ of the material derived out of plants. In India, there are at least 2,500 plant species having great medicinal value and most of them are growing wild. Out of these 750 plant species form the ingredient of 14,000 published recipes of Ayurveda, Sidha and Unani medicines (Dey, 1980; Kapoor, 1989). Information on their biological activity and chemical constituents is also available (Daniel, 2005; Kritikar and Basu, 1981). Use of Murraya koenigii for oral health care (Math and Balasubramaniam, 2004) and diabetes is well known (Kesari et al., 2005). Verma et al., 2012 have listed 25 ethno-medicinal plants of Kanag hill in Shimla region. In other studies it was reported that in the high altitude Himalayan areas, root is the most widely used plant parts (Sharma et al., 2004; Uniyal et al., 2002, 2006) root, leaf and whole plant are used in majority of the cases.

\section{Conclusion}

It can be concluded from the study that documentation of this knowledge is a novel information from the area of fringe villages around Shimla Water cstchment Sanctuary, Himachal Pradesh, India about the plants that are being used by the people living at the fringe villages. Thus, the present documentation not only highlights the uses of plants but also focuses on future conservation vis-à-vis providing leads for the betterment of human society.

\section{ACKNOWLEDGEMENTS}

The authors are thankful to rural people of the villages for providing valuable information and their co-operation during exploration trips.

\section{REFERENCES}

Ahluwalia, K.S. (1952). Medicinal plants of Kangra valley. Indian Forester. 78(4): 181-194.

Atkinson, E.T. (1882). Economic Botany of the Himalayan Region. Cosmo Publ., New Delhi.

Collett, H. (1902). Flora Simlensis. Thacker Spink and Co. Calcutta and Shimla, Reprinted (1971). B.S.M.P.S. Dehradun.

Daniel, M. (2005). Medicinal Plants: Chemistry and Properties.
Science Publishers, USA. p 266.

Dey AC (1980). Indian Medicinal Plants Used in Ayurvedic Preparations. Bishen Singh and Mahendra Pal Singh, Dehradun.

Dobriyal, R.M., Singh, G.S., Rao, K.S. and Saxena, K.G. (1997). Medicinal plant resources in Chhakinal watershed in north-western Himalaya. J. Herbs Spices \& Medicinal Plants 1997, 5: 15-27.

Gupta, R. (1961). Flora of Lam Dal. Indian Forester. 87(5): 316-324.

Gupta, R. (1971). Medicinal and aromatic plants of Bhandal ranges, Churah forest division, Chamba district, Himachal Pradseh. J. Bomb. Nat. His. Soc. 68: 791-803.

Hooker, J.D. (1872-1897). The Flora of British India, Vol. I-VIII. Lalit Mohan Basu, Allahabad

Kapoor, L.D. (1989). Handbook of Ayurvedic Medicinal plants. CRC, USA.

Kesari, A.N., Gupta, R.K. and Watal, G. (2005). Hypoglycemic Effect of Murraya koenigii on Normal and AlloxanDiabetic Rabbits. J. Ethnopharmacol. 97(2):247-251.

Kritikar, K.R. and Basu, B.D. (1981). Indian Medicinal Plants, vol I, II III and IV (second reprint) IBD, Dehradun.

Rastogi, M.A. (1960). Medicines from the wild. A case study of the Great Himalayan Park. The Indian Magazine of Her People and Culture,74-75.

Shabnam, S.R. (1964). Medicinal Plants of Chamba. Indian Forester.90: 50-63.

Sharma, P.K., Chauhan, N.S. and Brij, L. (2004). Observations on the traditional phytotherapy among the inhabitants of Parvati valley in western Himalaya India. J. Ethnopharmacol., 92:167-176.

Thakur, R.K., Puri, H.S. and Hussain, A. (1989). Major medicinal plants of India. CIMAP, Lucknow.

Math, M.V. and Balasubramaniam, P. (2004). Curry Leaves. Brit. Dental J., 197:519.

Uniyal, S.K., Awasthi, A., Rawat, G.S. (2002). Traditional and ethnobotanical uses of plants in Bhagirathi valley (western Himalaya). IJTK. 1(1):7- 19.

Uniyal, S.K., Singh, K.N., Jamwal, P., Brij, L. (2006). Traditional use of medicinal Plants among the Tribal communities of Chhota Bhangal, Western Himalaya. J. Ethnobiol. Ethnomed. 2:14.

Uniyal, M.R. \& Chauhan, N.S. (1971). Medicinal plants of Uhal valley in Kangra Forest Division. H.P. J. Res. Ind. Med. 6(3): 287-299.

Verma, R., Prakash, V. and Kumar, D. 2012. Ethnomedicinal uses of some plants of Kanag hill in Shimla, Himachal Pradesh, India. Int. J.RAP. 3(2): 319-322. 